\title{
Study of the influence of the mortar fine recycled aggregate ratio and the mixing sequence on the behavior of new mortars
}

\author{
Estudo da influência do teor de agregrado miúdo \\ reciclado de argamassa e da sequência de mistura no \\ comportamento de novas argamassas
}

\section{Gilberto Alves da Silva Neto Mônica Batista Leite}

\begin{abstract}
Gilberto Alves da Silva Neto Universidade Estadual de Feira de Santana Feira de Santana - BA - Brasil

Mônica Batista Leite Universidade Estadual de Feira de Santana

Feira de Santana - BA - Brasil

Recebido em 15/04/17 Aceito em 15/12/17

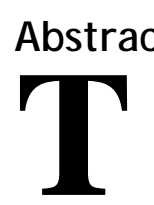
the influence of the mixing sequence over the performance of these mortars was analyzed. For this purpose, the replacement contents, by weight, of $20 \%$ and $40 \%$, and two mixing sequences were adopted: the sequence of the Brazilian Standard, NBR 7215 (ABNT, 1996) and an adaptation for mortars (MDE, in Portuguese, Mistura em Duas Etapas) of the Two-Stage Mixing Approach (TSMA), proposed by Tam, Gao and Tam (2005) for recycled concrete. The mortars were produced with cement CPV-ARI, using a mixing proportion of 1.0:5.0 (cement:aggregate, by weight) and a constant water/cement rate of 0.88. To analyze the behavior of the recycled mortars, they were tested in the fresh state and in the hardened state. The study concluded that the partial replacement of the NFA with the MFRA improved some properties of the recycled mortars: the air entrained content and the water absorption rate by capillarity decreased, and the mechanical performance increased. Regarding the influence of the mixing sequence, the adoption of the MDE promoted a better behavior on the mortar properties evaluated.

Keywords: Recycled mortar. Mixing sequence. Mortar fine recycled aggregate.

\section{Resumo}

Neste trabalho, investigou-se o comportamento de argamassas com a substituição parcial do agregado miúdo natural (AMN) pelo agregado miúdo reciclado de argamassa (AMRA), com dimensão menor que 2,4 mm. Além de analisar a influência da sequência de mistura no desempenho dessas argamassas. Para tal fim, adotou-se os teores de substituição, em massa, de $20 \%$ e 40\%, e dois métodos de mistura: o método da NBR 7215 (ABNT, 1996) e o método de mistura em duas etapas (MDE), que é uma adaptação para argamassa do método TSMA proposto por Tam, Gao e Tam (2005), para concretos reciclados. As argamassas foram produzidas com cimento CPVARI, utilizando um traço de 1,0:5,0 (cimento:agregado, em massa) e uma relação água/cimento constante de 0,88. Para a análise do comportamento das argamassas recicladas, as mesmas foram ensaiadas no estado fresco e no estado endurecido. O estudo permitiu concluir que a substituição parcial do AMN pelo AMRA melhorou algumas propriedades da argamassa reciclada, como o teor de ar incorporado e a absorção de água por capilaridade que foram reduzidos, além do desempenho mecânico dessas argamassas que foi incrementado. Quanto à influência da sequência de mistura, a adoção do MDE promoveu melhor comportamento nas propriedades avaliadas das argamassas.

Palavras-chaves: Argamassa reciclada. Sequência de mistura. Agregado miúdo reciclado de argamassa.
\end{abstract}

SILVA NETO, G. A. da; LEITE, M. B. Study of the influence of the mortar fine recycled aggregate ratio and the mixing sequence on the behavior of new mortars. Ambiente Construído, Porto Alegre, v. 18, n. 2, p. 53-69, abr./ jun. 2018. ISSN 1678-8621 Associação Nacional de Tecnologia do Ambiente Construído. 


\section{Introduction}

Within the industrial sector the greatest consumption of natural resources occurs in civil construction, which is responsible for the great generation and irregular disposal of construction and demolition waste (CDW) (OLIVEIRA; CABRAL, 2011). These factors are quite worrisome from the sustainability point of view, due to the big environmental impacts generated by the wrong destination of CDW, which is yet a problem to be solved in many countries, such as Brazil, and which also bring economic and social damages.

In Brazil, the irregular CDW disposal has caused floods, obstruction of galleries and silting of canals, proliferation of disease vectors, pollution, unnecessary increase of public management costs, among others. A possible solution to reduce these negative impacts is through the recycling of construction waste (ASSOCIAÇÃO..., 2015). The recycling of CDW can generate as sub products: crushed sand, gravel, crushed stone or cracked rock, which can be used in production of rendering mortars, in concrete, in seal blocks or bricks fabrication, base and sub-base for pavement works, pavement reinforcement and subgrade, among others (ASSOCIAÇÃO..., 2015).

As to the use of CDW in mortars, Miranda (2000) estimated a consumption of $1400 \mathrm{~kg}$ of construction waste per cubic meter of mortar produced. The author believes that the CDW recycling to produce mortars can become a feasible alternative to several types of buildings in Brazil, being possible to achieve a lower cost for their production when they are compared to traditional mortars. However, according to Silva et al. (2011), the heterogeneity and the presence of contaminants are the main difficulty in recycling these wastes. In addition, the high content of particles smaller than $0.075 \mathrm{~mm}$ and the high water absorption rate of the recycled aggregate are pointed out as limitations of its application, once they influence mortar properties such as: consistence, water retentivity, mechanical properties, drying shrinkage, among others (LE et al., 2017; MALTA et al., 2014; CORINALDESI; MORICONE, 2009; SILVA; BRITO; VEIGA, 2009; MIRANDA; SELMO, 2006).

Therefore, further studies are needed to use CDW in mortars, in order to contribute to the application of this material as a fine aggregate. These studies should evaluate aspects such as different production and mix design procedures in order to obtain better mortar properties in the fresh and in the hardened states. An example of a study that has proposed changes in the mixing sequence and which has shown good results when applied to recycled concrete, is the innovative Two-stage Mixing Approach (TSMA) developed by Tam, Gao and Tam (2005). With the TSMA method, the authors obtained increases in the compressive strength of the recycled concrete because of the coat of the recycled aggregate grains with the cement paste, which strengthened the transition zone of the components of the mixture. However, the influence of the mixing sequence is still poorly explored in recycled mortars studies.

It is known that the CDW composition depends on the stage in which the construction is (MIRANDA, 2000), the mortar fraction being one of the most found fractions in this material (LOVATO; MENEGATTI, 2015; MALTA; SILVA; GONÇALVES, 2013; OLIVEIRA; CABRAL, 2011), due to its utilization in several construction stages (masonry elevation, subfloor, coating, etc). Mixed fine recycled aggregates have been used by some authors in their studies with mortars (MALTA et al., 2014; CORINALDESI; MORICONE, 2009; SILVA et al., 2011; OLIVEIRA, 2012), others researchers used recycled aggregates exclusively from mortar wastes (SERRA; SANTANA; CABRAL, 2014), or ceramic wastes (SILVA; BRITO; VEIGA, 2009; HIGASHIYAMA et al., 2012). Taking into account the greater porosity of fine recycled materials, as observed by the authors mentioned above, and consequently the greater water absorption rate of recycled aggregate, the researchers have made a correction of the water/cement ratio of the recycled mixtures to produce the new mortars. Therefore, there was an increase in the water/cement ratio to avoid the influence of this aggregate characteristic on the mortar performance, in both, the fresh and the hardened states.

Oliveira (2012) pointed out in her studies that the presence of more water in the mixture favored the hydration reactions of the cement. Moreover, some characteristics of the recycled aggregate, such as a much more continuous granulometry and a greater grain roughness, promoted a beneficial influence on the strength increase of the studied mortars. However, the amount of water in the mixture must be controlled, since its excess can generate an inverse effect on the mechanical performance of the mortars.

As to the content of recycled aggregate in the mixture, Oliveira and Cabral (2011) determined in their studies that between 30 and $40 \%$ are the optimal replacement ratios of the natural aggregates by the mixed recycled ones in mortars. According to the authors, considering these levels of recycled aggregate content, the mortars presented maximum 
values in their properties, such as compressive strength and bond strength to the substrate. Other authors have obtained good results for different levels of FRA in mortars, such as 25\% of FRA (BRAGA; BRITO; VEIGA, 2012; SERRA; SANTANA; CABRAL, 2014; SOUZA, 2006), 50\% (SILVA et al., 2011; MALTA; SILVA; GONÇALVES， 2013)， 75\% (RESTUCCIA; SPOTO; FERRO, 2016; OLIVEIRA, 2012) or up to $100 \%$ (MARTINÉZ et al., 2016). However, it is believed that the optimum fine recycled aggregate (FRA) ratio adopted will depend on the composition of the material, the mixing proportion considered for the mixture, the properties analyzed, among other factors. For example, Oliveira (2012) that worked with mixed FRA obtained good results for mortars with a recycled aggregate content of $75 \%$. On the other hand, Serra, Santana and Cabral (2014) who adopted mortar fine recycled aggregate to produce recycled mortars, also tested the $75 \%$ content and did not obtain good results.

\section{Production of mortars with CDW}

The mixing process of the solid mortar constituents with water is one of the most important stages of the production of mortars, since the adopted procedures interfere directly or indirectly in their properties, both in the fresh and in the hardened states. In the next topic the mixing procedures recommended by ABNT will be presented, as well as innovations that were suggested by some authors about the mixing sequence, and the observed effects on produced mortars.

\section{Mixing sequence}

The mixing sequence, which is the order in which the mortar constituents are put into the mixing equipment, is poorly explored in most studies. Generally, the mixture is taken into account when dealing with lime mortars or with very absorbent aggregates, as is the case of recycled aggregates.

In laboratories, the mixing sequence of mortars is determined by NBR 13276 (ABNT, 2005b), following these steps:

(a) all necessary water is added in the mixer;

(b) the dry material (cement and fine aggregate) is added continuously over a period of $30 \mathrm{~s}$;

(c) it is mixed under low speed for $30 \mathrm{~s}$ and the equipment is turned off; (d) the flat beater is withdrawn from the mixer and within $60 \mathrm{~s}$ the internal walls of the bowl and flat beater are scraped; and

(e) the material is mixed for a further $30 \mathrm{~s}$.

Besides this procedure, many studies with mortars consider the mixing sequence described in Brazilian Standard NBR 7215 (ABNT, 1996), which consists on:

(a) initially all necessary water is added to the bowl;

(b) the cement is added;

(c) the materials are mixed under low speed for $30 \mathrm{~s}$;

(d) after this time the sand is gradually added for $30 \mathrm{~s}$, without stopping the mixture;

(e) the mixing speed is changed to high and the material is mixed for more $30 \mathrm{~s}$;

(f) the mixer is turned off for $1 \mathrm{~min}$ and $30 \mathrm{~s}$. In the first $15 \mathrm{~s}$ a scraping of the material adhered to the walls of the bowl and flat beater is carried out and in the remaining time ( $1 \mathrm{~min}$ and $15 \mathrm{~s}$ ) the mortar should be rested covered with a clean and moist cloth; and

(g) the mixer is turned on at high speed for another $1 \mathrm{~min}$.

At the construction site, the mixing of the mortars is usually done manually, according to the following steps:

(a) addition of the dry materials in the mixer;

(b) addition of about $90 \%$ of the fixed water;

(c) first mixing of materials;

(d) adjustment of workability with addition of more water or anhydrous mortar; and

(e) second mixing of the materials until the required workability is achieved (ANTUNES; JOHN; PILEGGI, 2006).

In order to improve the quality of the concrete composed by recycled aggregates, Tam, Gao and Tam (2005) proposed a new method of mixing concrete components called Two-Stage Mixing Approach (TSMA). In this method, the mixing process is divided into two parts, and the total water required by the concrete is divided and added at two different times of the process. Figure 1 shows the concrete mixing processes:

(a) the conventional mixing method; and

(b) the TSMA method. 
Figure 1 - Mixing procedures for concrete

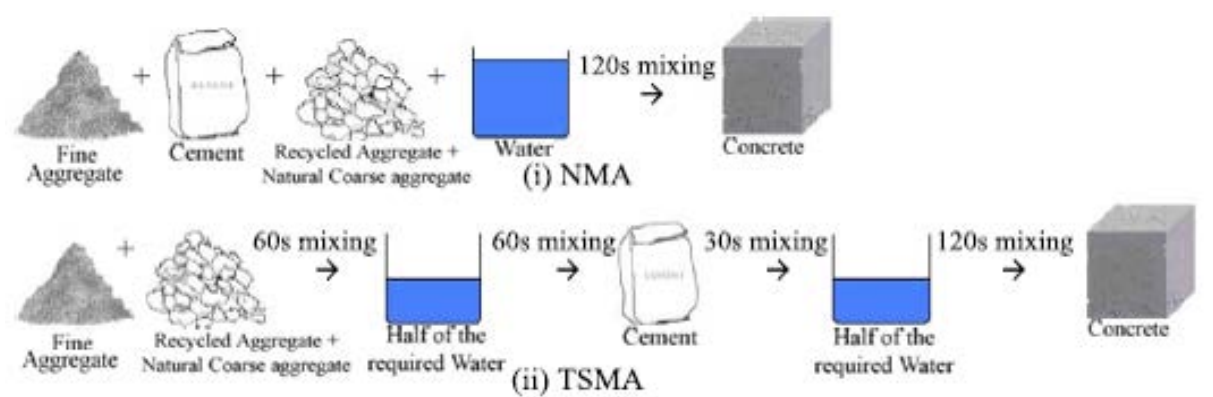

Source: Tam, Gao and Tam (2005).

By adopting this new mixing method, the authors were able to obtain significant improvement in the concrete strength compared to the conventional mixing method, called NMA (Figure 1i). The maximum observed increase was $21.19 \%$ at 28 days with a $20 \%$ substitution ratio of natural aggregate by the recycled concrete aggregate. Tam, Gao and Tam (2005) attributed the improvement in the concrete compressive strength to the development of a stronger transition zone around the recycled aggregates: if the paste-aggregate adhesion becomes bigger, the concrete strength also increases.

The TSMA mixing sequence is an adaptation of the pre-wetting method (FIGUEIRÊDO FILHO, 2011), which is often applied to recycled concrete, but rarely seen yet in studies with recycled mortars. The studies performed by Malta, Silva and Gonçalves (2013) and Lovato and Menegatti (2015) are examples of studies that have adopted the FRA prewetting method for the production of recycled mortars. Lovato and Menegatti (2015) observed that pre-wetting the FRAs with $80 \%$ of the total absorption rate was not efficient, because a higher water content was shown by the recycled mixture, thus resulting in low strength values. For the prewetting of the FRA with $50 \%$ of the total water absorption rate, regardless of the natural aggregate replacement ratio by FRA, the authors noticed a smaller amount of free water, as well as some improvements in the mortars' properties (tensile strength in flexion, compressive strength, water absorption by capillarity and bond strength). However, the performance achieved was still lower than that of the mortar used as reference.

According to Antunes, John and Pileggi (2006), changes in the mixing sequence adopted for the mortars production significantly influence its rheological behavior. Therefore, such approach in the studies with recycled mortars is fundamental in the researches conducted for improvements of this material.
Based on the above considerations, this study chose to use the mortar waste as fine aggregate to produce new mortars. Besides analyzing the effects of an adaptation for mortars of the mixing sequence proposed by Tam, Gao and Tam (2005) for concrete, the behavior of the produced mortars will also be evaluated. With the conduction of this study, there is the interest, therefore, to broaden the knowledge about this subject. The aim of this study is to analyze the influence of the use of the mortar fine recycled aggregate on the behavior of recycled mortars, as well as the effect of the mixing sequence on the characteristics of the mortars.

\section{Methods}

\section{Materials}

The cement utilized to produce the recycled mortars was CPV - ARI, once it has a reduced content of additions, allowing, therefore, a better analyzing of the influence of the MFRA in the mortars, mainly the presence of fine fraction. The cement was characterized according to the Brazilian standard specification NBR 5733 (ABNT, 1991). The CPV ARI showed a specific gravity of $3.09 \mathrm{~g} / \mathrm{cm}^{3}$.

The natural fine aggregate (NFA) adopted was the fine sand from Alagoinhas (a city in the state of Bahia, Brazil) that is commonly used in the region of the study, and the mortar fine recycled aggregate (MFRA) used was the material processed by Figueirêdo Filho (2011). The latter came from rendering and wall bedding mortar found in CDW collected from irregular disposal sites in the city of Feira de Santana, Bahia. Once the MFRA used by Figueirêdo Filho (2011) was that with maximum size aggregate $\left(\mathrm{D}_{\max }\right)$ of $4.8 \mathrm{~mm}$, and considering the good results in mortars with recycled fine aggregates with $D_{\max }$ of $2.4 \mathrm{~mm}$ (MIRANDA, 2000; GOMES et al., 2010) it was necessary to sieve this material again using the sieve of $2.4 \mathrm{~mm}$. Table 1 shows the results of NFA and MFRA characterizations. 
Table 1 - Aggregate characterizations

\begin{tabular}{c|c|c}
\hline Evaluated Properties - Methods & $\begin{array}{c}\text { Natural } \\
\text { NFA }\end{array}$ & $\begin{array}{c}\text { Recycled } \\
\text { MFRA }\end{array}$ \\
\hline Maximum size aggregate (mm) - NBR NM 248(ABNT, 2003) & 1.20 & 2.40 \\
Fineness Modulus - NBR NM 248 (ABNT, 2003) & 1.77 & 1.88 \\
Specific Gravity (g/cm³) - NBR 52 (ABNT, 2009) & 2.62 & 2.48 \\
Water Absorption (\%) - NBR NM 30 (2003) & 0.1 & 7.2 \\
Fine content (\%) - NBR NM 46 (ABNT, 2003) & 2.1 & 10.9 \\
\hline
\end{tabular}

It is important to highlight that, comparing the NFA and MFRA, it can be observed that: the recycled aggregate is grosser than the natural aggregate, since its fineness modulus is $6 \%$ bigger than the one of NFA; the absorption rate of the MFRA is 72 times bigger than the absorption rate of the NFA; the fine content of the MFRA is about 5 times bigger than the one of NFA; and the specific gravity of the MFRA is about 5\% smaller, than the one of NFA.

Another important characteristic of the aggregates that deserves highlight is their particle-size distribution. Figure 2 reveals the granulometric curves of the NFA and the MFRA, besides the curves of the compositions of aggregates of each mixture.

It can be seen that, the MFRA has a particle-size distribution more continuous than the NFA, which can promote a better settlement of the aggregates, improving this way the packing of the mixing. In addition, while the MFRA content increased in the mixture, the particle-size distribution of the composition of aggregates became less discontinuous, being the less discontinuous composition the one with $40 \%$ of MFRA and $60 \%$ of NFA.

\section{Production of the mortars}

The mortars were produced to a mixing proportion of 1.0:5.0 (cement:aggregate), by weight, and using two mixing sequences:

(a) the one recommended by the Brazilian standard NBR 7215 (ABNT, 1996); and

(b) an adaptation for mortars of the TSMA proposed by Tam, Gao and Tam (2005) for recycled concretes, which in this study will be called MDE (in Portuguese, Mistura em Duas Etapas, that may be called in English 'Mixture in Two Stages' - MTS).

The adaptation for mortars of the TSMA (TAM; GAO; TAM, 2005), consisted on withdrawing the initial stage of this procedure, which mixes the fine and coarse aggregates for 60 seconds, once there are not coarse aggregates in mortars. Figure 3 outlines the MDE.

For each mixing sequence a reference mix and two others were produced, one with $20 \%$ and the other with $40 \%$ of substitution ratio of NFA by MFRA. Thus, six mortar mixtures were produced.

To avoid differences on material volume, generated by the differences on the specific gravities of the MFRA and the NFA, a volume compensation to the recycled aggregate was adopted.

The water/cement ratio was established for the reference mixture, produced with the mixing sequence of the Brazilian standard NBR 7215 (ABNT, 1996) to obtain a consistence index of $265 \pm 5 \mathrm{~mm}$, determined according to NBR 13276 (ABNT, 2005b). Therefore, the w/c ratio found was 0.88 . It was kept constant for all mixes evaluated in this study in order to observe the influence of the MRFA content and also the MDE on the consistency of the mortars produced.

The mixer utilized to produce the samples tested in the fresh state was Contenco ${ }^{\circledR}$, model I-3010, and in the hardened state, Amadio ${ }^{\circledR}$, model 20, serial LA. Their useful capacities were, respectively, 5 and 20 liters.

\section{Mortar properties in the fresh state}

With the objective of observing the mortar properties in the fresh state the following tests were conducted:

(a) determination of consistence, according to NBR 13276 (ABNT, 2005b);

(b) water retentivity, according to NBR 13277 (ABNT, 2005c); and

(c) air entrained content and bulk density, according to NBR 13278 (ABNT, 2005d). 
Figure 2 - Granulometric curves of the aggregates utilized and the compositions in each mixture

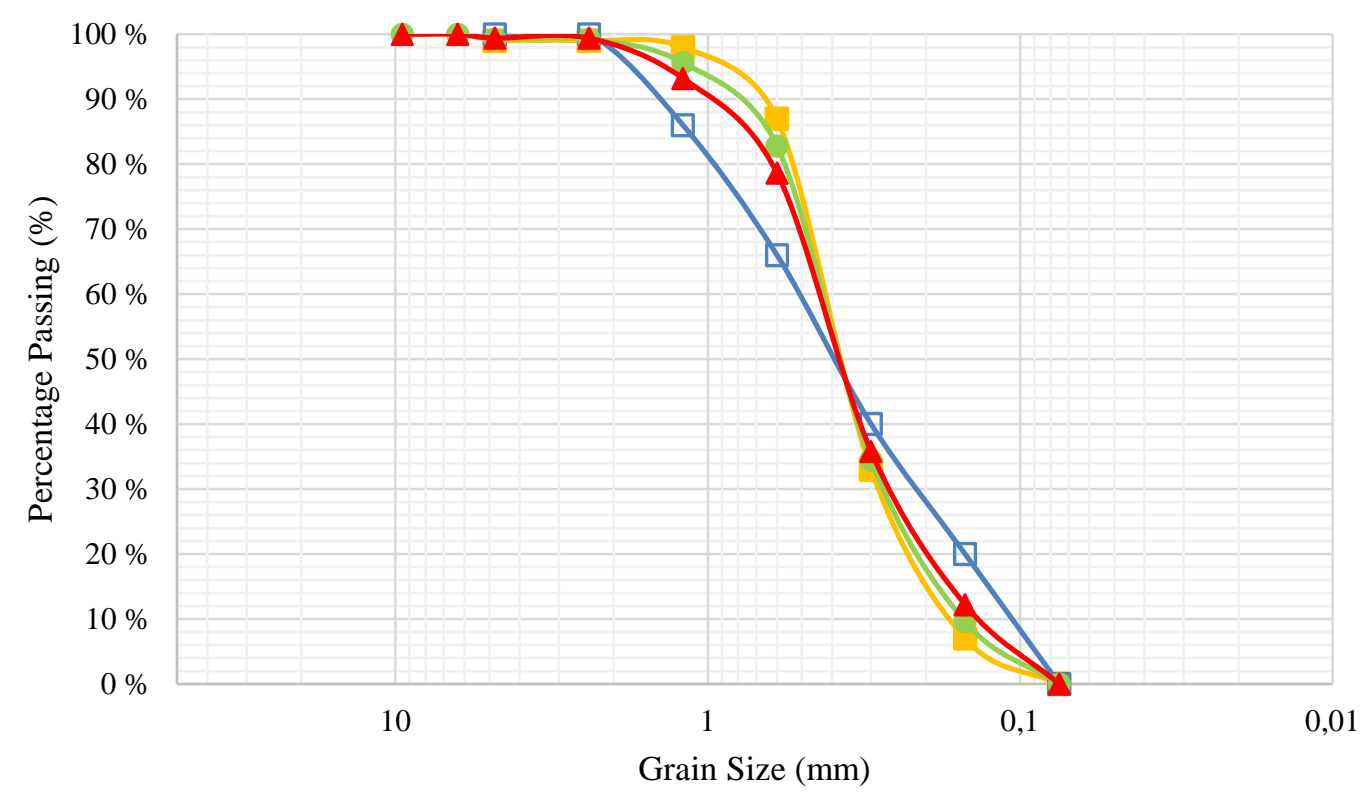

- NFA $\square$ MFRA - Mixture 20\% MFRA $\longrightarrow$ Mixture 40\% MFRA

Figure 3 - MDE mixing sequence for the production of the mortars

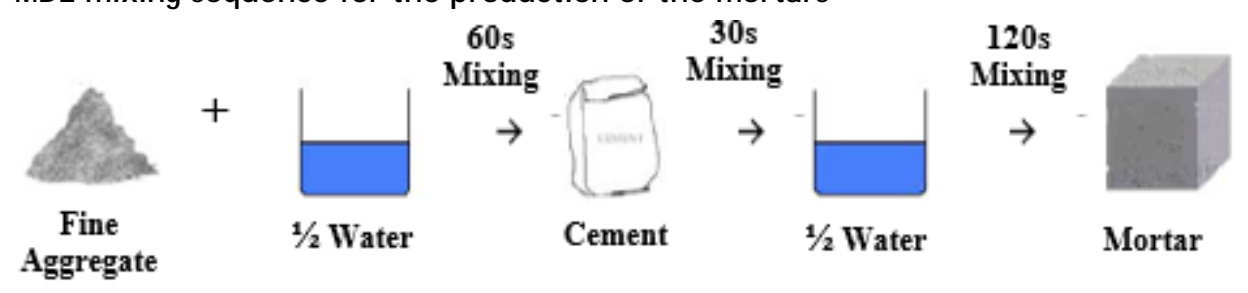

\section{Mortar properties in hardened state}

With the objective of observing the mortar properties in the hardened state the following tests were realized:

(a) determination of water absorption by capillarity, at 28 days of age, according to NBR 15259 (ABNT, 2005f);

(b) determination of the flexural and the compressive strength at 7 and 28 days, according to NBR 13279 (ABNT, 2005e); and

(c) determination of the water absorption by immersion, the void index, and the specific gravity, at 28 days of age, according to NBR 9778 (ABNT, 2005a).

\section{Results and discussions}

\section{Mortar properties in the fresh state}

Table 2 shows the average results, the standard deviation and the coefficient of variation obtained for the consistence index (ABNT, 2005b), water retentivity (ABNT, 2005c), air entrained content and bulk density (ABNT, 2005d) of the mortars produced with the two different mixing sequences and three different replacement ratios of NFA by MFRA.

It is observed that the increase of the MFRA content in the mixture reduced the consistence index and the air entrained content of the studied mortars, and increased their capacity of water retentivity and their bulk density, for both mixing sequences, when they were analyzed individually. Although the increase of the MFRA content had reduced the consistence index of the recycled mortars, they kept themselves workable an slightly dry. 
Table 2 - The mean, the standard deviation, and the coefficient of variation of the results obtained for the consistence index, water retentivity, air entrained content and bulk density of the produced mortars

\begin{tabular}{|c|c|c|c|}
\hline \multicolumn{4}{|c|}{ Consistence Index } \\
\hline Mixing Sequence & $\begin{array}{c}\text { REF } \\
\mathrm{C} \pm \mathrm{SD}(\mathrm{CV}) \\
\mathrm{mm} \pm \mathrm{mm}(\%)\end{array}$ & $\begin{array}{c}\text { 20\%MFRA } \\
\mathrm{C} \pm \mathrm{SD}(\mathrm{CV}) \\
\mathrm{mm} \pm \mathrm{mm}(\%)\end{array}$ & $\begin{array}{c}\text { 40\%MFRA } \\
\mathrm{C} \pm \mathrm{SD}(\mathrm{CV}) \\
\mathrm{mm} \pm \mathrm{mm}(\%)\end{array}$ \\
\hline NBR 7215 & $270 \pm 1.1(0.4)$ & $265 \pm 0.2(0.1)$ & $243 \pm 0.5(0.2)$ \\
\hline MDE & $276 \pm 0.2(0.1)$ & $248 \pm 1.4(0.6)$ & $230 \pm 5.7(2.5)$ \\
\hline \multicolumn{4}{|c|}{ Water Retentivity } \\
\hline Mixing Sequence & $\begin{array}{c}\text { REF } \\
\text { Ra } \pm \text { SD }(\mathrm{CV}) \\
\% \pm \%(\%)\end{array}$ & $\begin{array}{c}\text { 20\%MFRA } \\
\text { Ra } \pm \text { SD (CV) } \\
\% \pm \%(\%)\end{array}$ & $\begin{array}{c}\text { 40\%MFRA } \\
\text { Ra } \pm \text { SD (CV) } \\
\% \pm \%(\%)\end{array}$ \\
\hline NBR 7215 & $64 \pm 0.0(0.1)$ & $68 \pm 0.8(1.1)$ & $74 \pm 2.2(2.9)$ \\
\hline MDE & $64 \pm 0.9(1.4)$ & $69 \pm 0.9(1.3)$ & $74 \pm 0.6(0.9)$ \\
\hline \multicolumn{4}{|c|}{ Air Entrained Content } \\
\hline Mixing Sequence & $\begin{array}{c}\text { REF } \\
\mathrm{A} \pm \mathrm{SD}(\mathrm{CV}) \\
\% \pm \%(\%) \\
\end{array}$ & $\begin{array}{c}\text { 20\%MFRA } \\
\mathrm{A} \pm \mathrm{SD}(\mathrm{CV}) \\
\% \pm \%(\%)\end{array}$ & $\begin{array}{c}\text { 40\%MFRA } \\
\mathrm{A} \pm \mathrm{SD}(\mathrm{CV}) \\
\% \pm \%(\%)\end{array}$ \\
\hline NBR 7215 & $8.2 \pm 0.32(3.9)$ & $7.0 \pm 0.27(3.9)$ & $5.5 \pm 0.64(11.6)$ \\
\hline MDE & $8.7 \pm 0.05(0.5)$ & $7.0 \pm 0.06(0.8)$ & $5.7 \pm 0.34(6.0)$ \\
\hline \multicolumn{4}{|c|}{ Bulk Density } \\
\hline Mixing Sequence & $\begin{array}{c}\text { REF } \\
\mathrm{d} \pm \mathrm{SD}(\mathrm{CV}) \\
\mathrm{kg} / \mathrm{m}^{3} \pm \mathrm{kg} / \mathrm{m}^{3}(\%)\end{array}$ & $\begin{array}{c}\text { 20\%MFRA } \\
\mathrm{d} \pm \mathrm{SD}(\mathrm{CV}) \\
\mathrm{kg} / \mathrm{m}^{3} \pm \mathrm{kg} / \mathrm{m}^{3}(\%)\end{array}$ & $\begin{array}{c}\text { 40\%MFRA } \\
\mathrm{d} \pm \mathrm{SD}(\mathrm{CV}) \\
\mathrm{kg} / \mathrm{m}^{3} \pm \mathrm{kg} / \mathrm{m}^{3}(\%)\end{array}$ \\
\hline NBR 7215 & $2029 \pm 7.0(0.3)$ & $2037 \pm 6.0(0.3)$ & $2049 \pm 13.9(0.7)$ \\
\hline MDE & $2018 \pm 1.0(0.1)$ & $2037 \pm 1.3(0.1)$ & $2045 \pm 7.4(0.4)$ \\
\hline
\end{tabular}

Note: SD - Standard Deviation; and

CV - Coefficient of Variation.

Regarding to the consistence index, the behavior can be explained by the greater water absorption of the grains of MFRA (absorption rate 72 times greater than that of the NFA), that made the mixture rougher and increased the friction between the grains of aggregates. It is important to remember that the water/cement ratio was kept constant in all mixtures, in order to evaluate how big or short the changes would be in the mortars' fresh state behavior with the two different mixing sequences and the different MFRA content studied. The studies with recycled mortars of Malta, Silva and Gonçalves (2013) and Martinéz et al. (2016) also observed such behavior. The roughness of the mixture also can be related to the most irregular and elongated shape and rougher surface (Figure 4a and 4b) of the grains of the MFRA, opposite to the almost spherical shape and the smooth surface (Figure 4c and 4d) of the grains of NFA used in this study.

The greater porosity of the MFRA (which increases its absorption, retaining part of the mixing water and making it difficult for this water to exit the grains), combined to the greater presence of

ISILVA, N. G. Argamassa de Revestimento de Cimento, Cal e Areia Britada de Rocha calcária. Curitiba, 2006. Dissertação powdery materials in this aggregate (that promote a greater water adsorption to the surface of fine particles with bigger specific area), also can be pointed out as causes for the increase of the water retentivity of the recycled mortars, what is similar to what was observed by Neno, Brito and Veiga (2014), Silva, Brito and Veiga (2009) and Silva (2006 ${ }^{1}$ apud GOMES et al. 2010). In addition, the reduction of the effective water/cement ratio generated by the greater water absorption of the MFRA, reduced the air entrained content and, consequently, increased the bulk density of the mixtures.

By comparing the mixing sequences (NBR 7215 and MDE); it is noticed that for the same replacement ratio there was a reduction of the consistence index for the MDE sequence. This behavior can be explained by the first stage of MDE, where half of the mixing water gets in touch directly to the dry grains of the recycled aggregate, making the water absorption easier and raising the reduction of the effective mixing water if compared with the sequence of NBR 7215 (ABNT, 1996). To this latter sequence the water gets in touch first with 
the cement paste. Also the mixing time that is longer in the MDE than in the Brazilian standard mixing sequence, promotes a bigger $\mathrm{w} / \mathrm{c}$ ratio reduction. However, by comparing the reference mortars of the two mixing sequences, it can be noticed that the consistence index of the reference mortar produced by the MDE mixing sequence increased in relation to the other reference mortar. This behavior can be explained by the greater dispersion of the cement combined to the grains of NFA (mostly rounded and smooth as shown in Figures 4c and 4d), already wet with part of the mixing water (first stage of the MDE), showing more grains of NFA covered with the cement paste, what increases its flow, mainly when the second half of the mixing water (second stage of the MDE) is added. Regarding the water retentivity, the air entrained content and the bulk density of the studied mortars, the alteration of the mixing sequence did not generate great influence on the results.

The results show that the increase of the MFRA content in the mixtures favored the water retentivity and the air entrained content of the mortars, as observed in the studies of Gomes et al. (2010) and Oliveira (2012). As Figure 5 presents, the water retentivity increased $6 \%$ and $8 \%$ in relation to the reference mortar, for the content of $20 \%$ of MFRA (for the mixing sequences of the NBR 7215 and MDE, respectively) and $16 \%$ for the content of $40 \%$ of MFRA in relation to the reference, in both mixing approaches.

\section{Figure 4 - Images of NFA and MFRA surface and shape features for grain size dimensions between 1.2 to $0.6 \mathrm{~mm}$ : a) MFRA - Resolution of 2X0.67 times; b) MFRA - Resolution of 2X3.0 times; c) FNA - Resolution of $2 \times 0.67$ times; d) FNA - Resolution of $2 \times 3.0$ times}

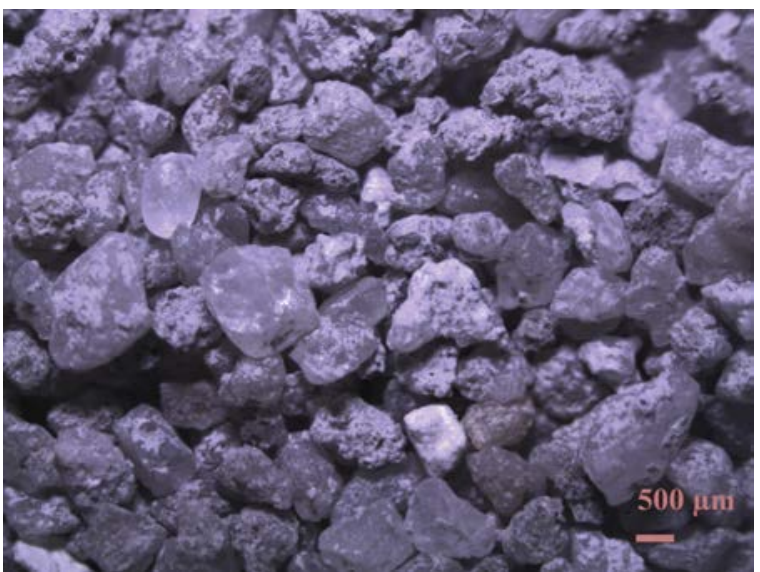

(a)

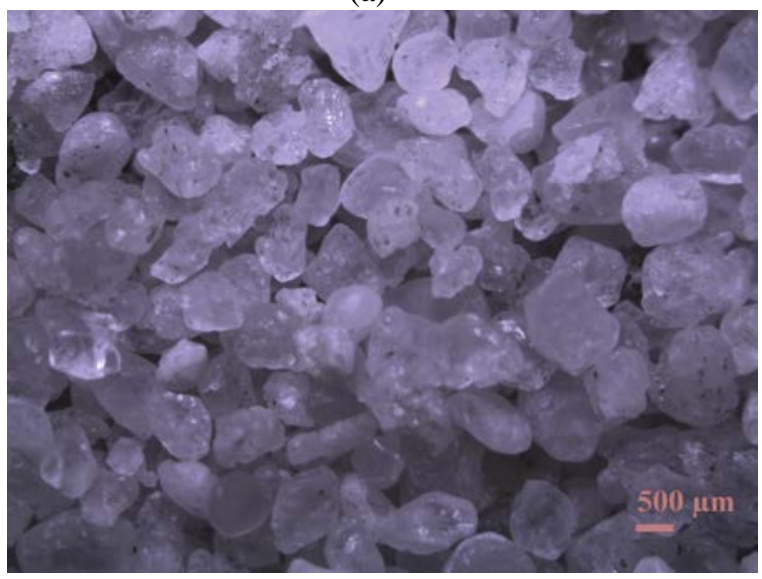

(c)

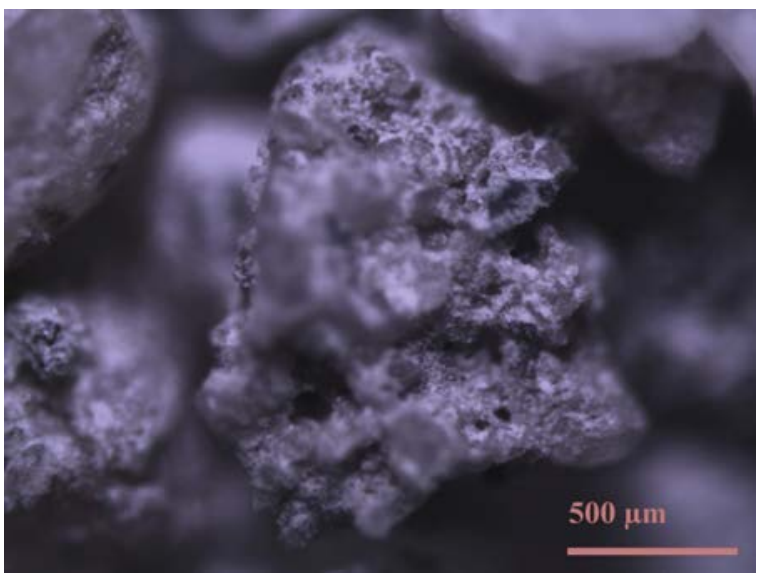

(b)

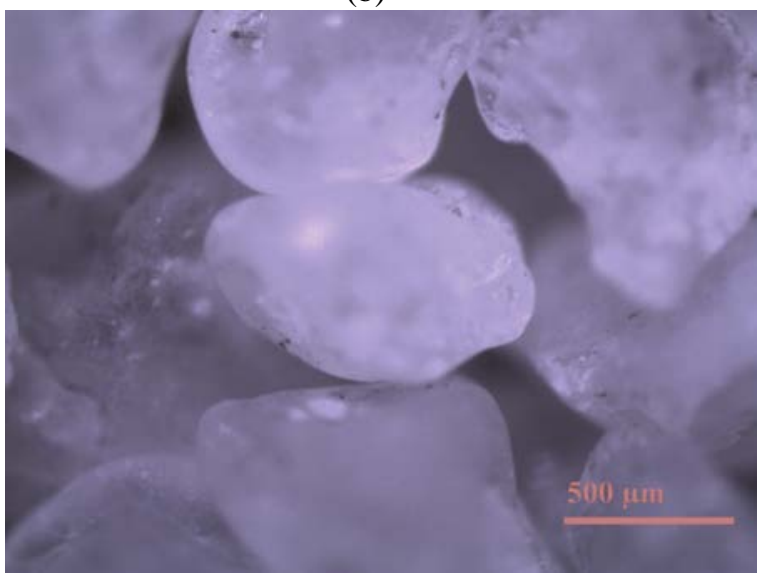

(d) 
Figure 5 - Relative results: (a) water retentivity - standard mixing sequence; (b) water retentivity MDE sequence; (c) air entrained content - standard mixing sequence; and (d) air entrained content MDE mixing sequence

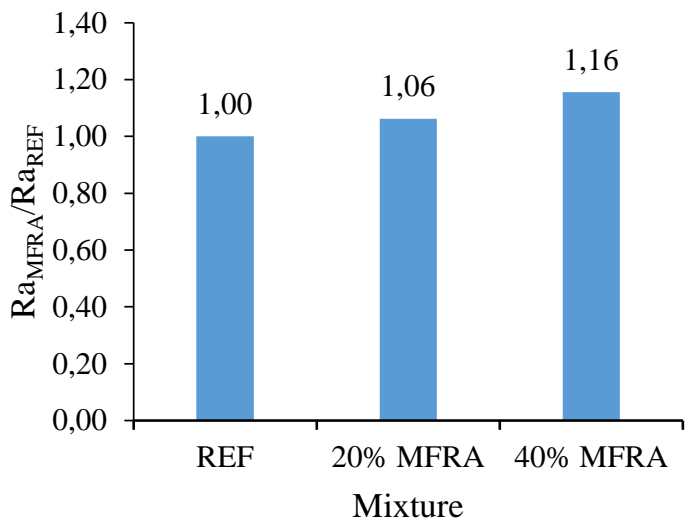

(a)

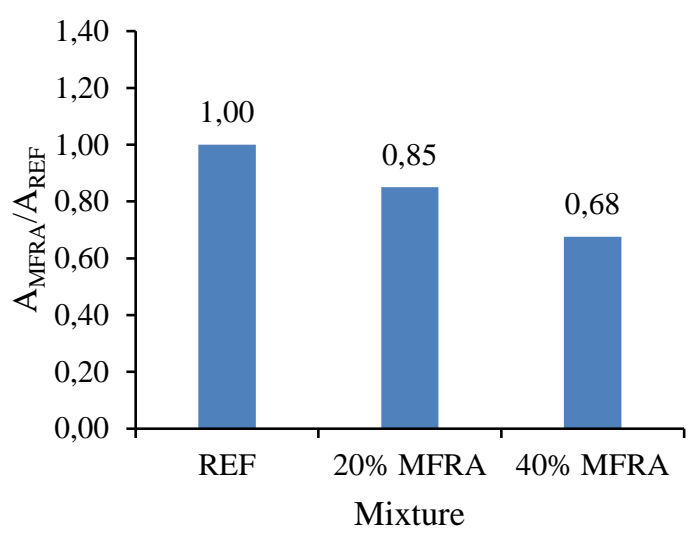

(c)

Regarding the air entrained content, the greatest reductions of this property occurred to the mixture of $40 \%$ MFRA of both mixing sequences (32\% and $34 \%$, for the sequences of the NBR 7215 (ABNT, 1996) and MDE, respectively). The observed reduction must be mainly associated to the reduction of the effective water/cement ratio, because with less free water in the mixture, less water will evaporate, so less bubbles will be produced. This behavior is quite favorable to the mixture, once the air entrained content influences negatively on the porosity and consequently on the water absorption and mechanical strength of the mortars, as also detected by Romano et al. (2007). However, the reduction of the air entrained content may increase the thermal expansion coefficient of the mortars in such a way that can probably reduce their durability. Therefore, the effects of that property must be better studied.

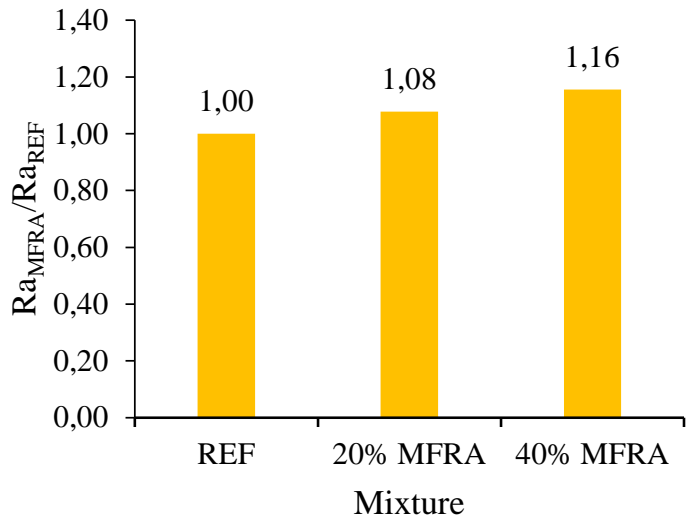

(b)

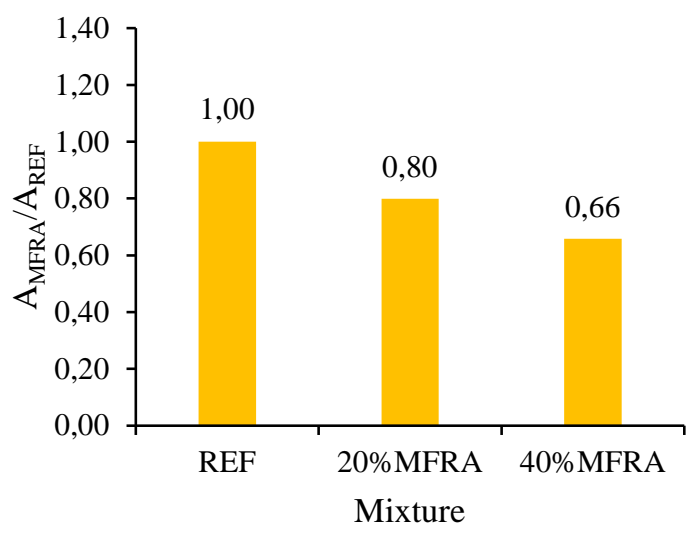

(d)

\section{Mortar properties in the hardened state}

\section{Flexural and compressive strength}

Table 3 presents the mean, the standard deviation and the coefficient of variation of the results of flexural and compressive strength (NBR 13279, ABNT, 2005e) of the produced mortars with the two mixing sequences and at two rupture ages (7 and 28 days).

\section{Mortar properties in the hardened state}

\section{Flexural and compressive strength}

Table 3 presents the mean, the standard deviation and the coefficient of variation of the results of flexural and compressive strength (ABNT, 2005e) of the produced mortars with the two mixing sequences and at two rupture ages (7 and 28 days). 
Table 3 - The mean, the standard deviation, and the coefficient of variation of the results of flexural and compressive strength of the studied mortars

\begin{tabular}{|c|c|c|c|c|c|c|}
\hline \multicolumn{7}{|c|}{ Flexion } \\
\hline \multirow[t]{2}{*}{$\begin{array}{l}\text { Mixing } \\
\text { Sequence }\end{array}$} & \multicolumn{2}{|c|}{$\begin{array}{c}\text { REF } \\
\mathrm{f}_{\mathrm{t}} \pm \mathrm{SD}(\mathrm{CV}) \\
\mathrm{MPa} \pm \mathrm{MPa}(\%)\end{array}$} & \multicolumn{2}{|c|}{$\begin{array}{c}\text { 20\%MFRA } \\
\mathrm{f}_{\mathrm{t}} \pm \mathrm{SD}(\mathrm{CV}) \\
\mathrm{MPa} \pm \mathrm{MPa}(\%)\end{array}$} & \multicolumn{2}{|c|}{$\begin{array}{c}\text { 40\%MFRA } \\
\mathrm{f}_{\mathrm{t}} \pm \mathrm{SD}(\mathrm{CV}) \\
\mathrm{MPa} \pm \mathrm{MPa}(\%)\end{array}$} \\
\hline & 7 days & 28 days & 7 days & 28 days & 7 days & 28 days \\
\hline $\begin{array}{l}\text { NBR } \\
7215 \\
\end{array}$ & $3.7 \pm 0.2(5.4)$ & $4.2 \pm 0.4(8.3)$ & $4.0 \pm 0.4(8.9)$ & $6.0 \pm 0.3(4.2)$ & $5.4 \pm 0.3(4.6)$ & $5.8 \pm 0.3(4.5)$ \\
\hline MDE & $4.3 \pm 0.2(5.1)$ & $6.1 \pm 0.1(1.2)$ & $4.5 \pm 0.2(4.7)$ & $6.3 \pm 0.2(2.7)$ & $5.4 \pm 0.1(2.2)$ & $6.9 \pm 0.5(7.2)$ \\
\hline \multicolumn{7}{|c|}{ Compression } \\
\hline \multirow[t]{2}{*}{$\begin{array}{c}\text { Mixing } \\
\text { Sequence }\end{array}$} & \multicolumn{2}{|c|}{$\begin{array}{c}\text { REF } \\
\mathrm{f}_{\mathrm{c}} \pm \mathrm{SD}(\mathrm{CV}) \\
\mathrm{MPa} \pm \mathrm{MPa}(\%)\end{array}$} & \multicolumn{2}{|c|}{$\begin{array}{c}\text { 20\%MFRA } \\
\mathrm{f}_{\mathrm{c}} \pm \mathrm{SD}(\mathrm{CV}) \\
\mathrm{MPa} \pm \mathrm{MPa}(\%)\end{array}$} & \multicolumn{2}{|c|}{$\begin{array}{c}\text { 40\%MFRA } \\
\mathrm{f}_{\mathrm{c}} \pm \mathrm{SD}(\mathrm{CV}) \\
\mathrm{MPa} \pm \mathrm{MPa}(\%)\end{array}$} \\
\hline & 7 days & 28 days & 7 days & 28 days & 7 days & 28 days \\
\hline $\begin{array}{l}\text { NBR } \\
7215 \\
\end{array}$ & $9.7 \pm 0.3(3.3)$ & $13.5 \pm 0.4(2.8)$ & $11.3 \pm 0.2(1.5)$ & $14.9 \pm 0.3(2.1)$ & $12.5 \pm 0.3(2.2)$ & $17.5 \pm 0.3(2.0)$ \\
\hline MDE & $11.0 \pm 0.3(3.0)$ & $14.3 \pm 0.2(1.6)$ & $12.2 \pm 0.4(3.1)$ & $16.2 \pm 0.3(1.8)$ & $13.0 \pm 0.4(2.9)$ & $16.7 \pm 0.4(2.3)$ \\
\hline
\end{tabular}

Note: SD - standard deviation; and

$\mathrm{CV}$ - coefficient of variation.

The results shown in Table 3 reveal that for both mixing sequences, and both rupture ages of the produced mortars, the increase of the MFRA content increased the flexural and compressive strength of these mortars. In addition, when the MDE mixing sequence was adopted, the mechanical performance of the produced mortars was improved, at both rupture ages, comparing them to these mortars that were produced with the NBR 7215 (ABNT, 1996) mixing sequence; except for the compressive strength of the mixture 40\%MFRA, at 28 days, where the compressive strength was reduced when the MDE mixing sequence was adopted.

In Figure 6, it can be seen that for the mortars produced with the mixing sequence of the NBR 7215 (ABNT, 1996) (Figure 6a) there was a greater increase of the flexural strength, $43 \%$ and $38 \%$,for the mixture 20\%MFRA and 40\%MFRA, respectively, comparing them to the reference mortar of the same mixing sequence. Considering the same mixtures that were produced with the MDE mixing sequence (Figure 6b), this increase was of $3 \%$ and $13 \%$ (mixture 20\%MFRA and 40\%MFRA, respectively). Regarding the compressive strength, the mixture 40\%MFRA that was produced with the mixing sequence of the NBR 7215 (ABNT, 1996) was the one which presented the greatest strength increase (30\%), in relation to the reference mortar of the same mixing approach (Figure 6c).
Comparing the obtained results of mechanical behavior to the different mixing sequences, it was observed that in the flexural strength, at 28 days (Figure 7a), there was a great strength increase (45\%) for the reference mortar of the MDE when compared to the REF mixture of the sequence of the NBR 7215 (ABNT, 1996). With reference to the compressive strength (Figure 7b), a strength increase in the produced mortars with MDE was also noticed, when compared to the mixtures of the mixing sequence of the Brazilian standard, except the mixture 40\%MFRA, where there was a reduction of $5 \%$.

The increment in the strength of the studied recycled mortars, both in the flexion and compression, is due, mainly, to the reduction of the effective water/cement ratio, once the amount of mixing water was constant. It is important to point out that due to the greater absorption rate of the MFRA (72 times greater than the of the NFA), the recycled aggregate absorbs part of the mixing water, mainly in the MDE (once the mixing time of this mixing method is longer than the one of the Brazilian standard method). Thus, this absorbed water cannot easily leave the interior of the grains, increasing the water retentivity. It is also believed, that the greater water retentivity benefits and prolongs the reactions of cement hydration, benefiting therefore, the mechanical performance of the recycled mortars, as also observed by Neno, Brito and Veiga (2014) and Oliveira (2012). 
Figure 6 - Relative results of the mechanical properties (at 28 days): (a) $\mathrm{ft}$ - standard mixing sequence; (b) ft-MDE mixing sequence; (c) fc - standard mixing sequence; and (d) fc - MDE mixing sequence

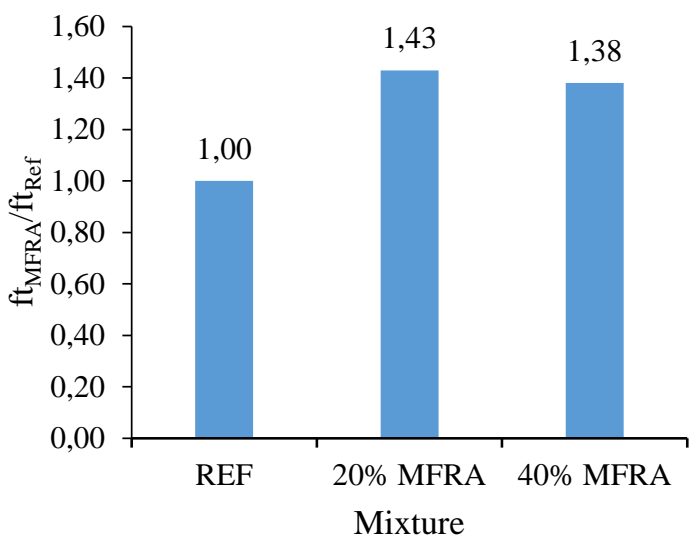

(a)

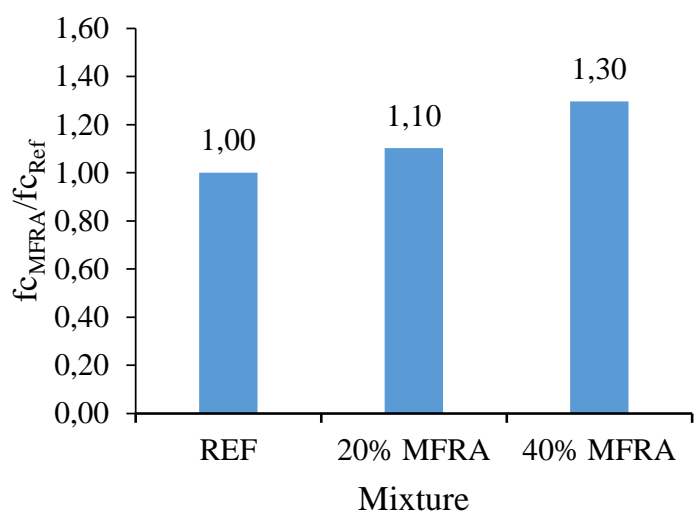

(c)

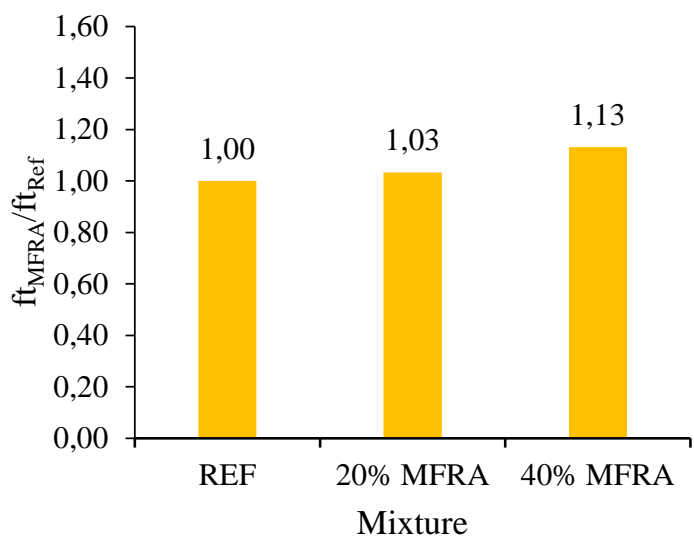

(b)

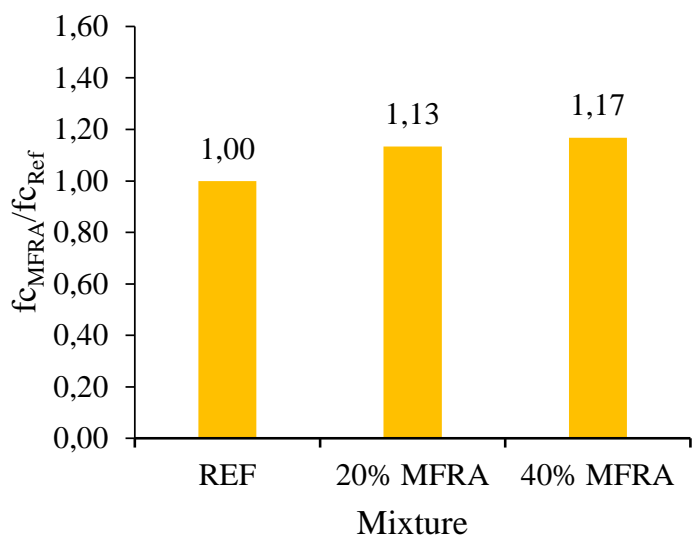

(d)

Figure 7 - Relative results of strength between the mixing sequences, at 28 days of age: (a) flexural strength; and (b) compressive strength

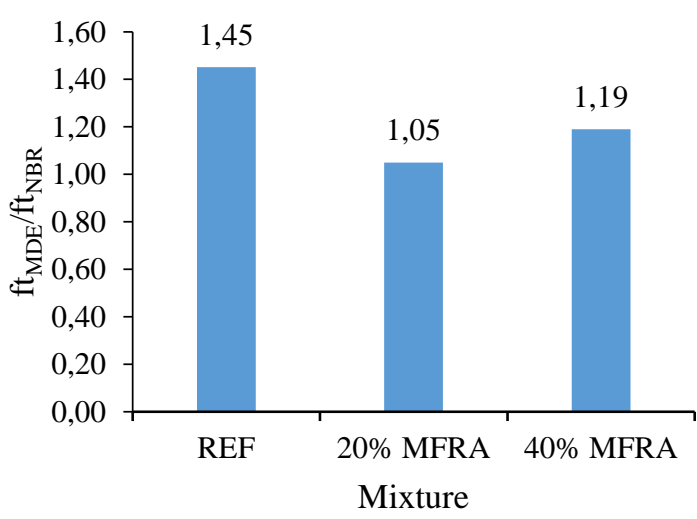

(a)

The reduction of the air entrained content can also be an influence to the improvement of the mechanical strength of the mortars with MFRA, once this reduction promotes the reduction of the

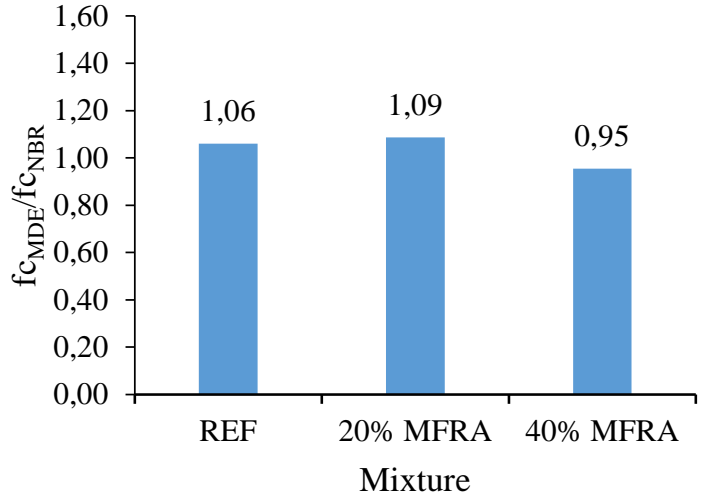

(b)

total porosity, contributing, therefore, to the mechanical performance of those mortars, as seen in the studies of Gomes et al. (2010). In addition, the greater content of material finer than $75 \mu \mathrm{m}$, 
which may fill the voids of the mortar granular structure; the possible presence of anhydrous grains of cement, which can be hydrated later; the surface texture, that benefits the adhesion of this aggregate to the new paste; and the continuous granulometry of the MFRA that improves the packing of the mixture, also may be aspects to be considered to analyze the increase of the mechanical performance of the studied mortars. Similar to the considerations of Braga, Brito and Veiga (2012) and Oliveira (2012) in their studies with mixed FRA, which the greatest fraction of CDW was mortar. However, the benefits of the greater content of material finer than $75 \mu \mathrm{m}$ for the mechanical strength of the mortars with MFRA, can only be confirmed after more studies of the unit weight of the dry mixtures.

Regarding the influence of the MDE mixing sequence, the improvement of the mechanical strengths, both in flexural tensile and compression strength, may have been generated by the development of a stronger transition zone around the grains of aggregates (natural and recycled), due to the formation of a thin layer of cement paste on the surface of the grains. In the case of the recycled aggregates, the cement paste also helped to fill the surface cracks and pores of the grains (seen in Figure 4b), improving the greater interlocking between cement paste and MFRA, as concluded by Tam, Gao and Tam (2005) in their application of the TSMA sequence in the production of recycled concrete, and, the beneficial effects of reducing the effective water/cement ratio, once it is believed that such reduction was higher in mortars of the MDE sequence. However, it would be appropriate to perform a microscopic study of the mortar structure to understand this behavior, and also try to understand the small reduction of the compressive strength of the mortar at 28 days, with $40 \%$ of MFRA when adopting the MDE sequence.

\section{Water absorption by capillarity}

Table 4 presents the mean, the standard deviation, and the coefficient of variation for the water absorption by capillarity of the studied mortars.

Figure 8 shows the graph for the water absorption by capillarity of the studied mortars, expressing their behavior with the variation of the MFRA content and the mixing sequence.

When comparing the results obtained for each mixing sequence, it was observed that the mortars that were produced following the MDE mixing sequence showed a reduction of the water absorption by capillarity for all the MFRA contents, in comparison to the same mixtures obtained by the sequence of the Brazilian standard NBR 7215 (ABNT, 1996). The most expressive reduction (15\%) was found for the 40\%MFRA mixture at 10 min of the test and $21 \%$ for the same mixture at 90 $\min$.

The reduction of the water absorption by capillarity can be explained by the higher fine content of the MFRA, which is about 5 times the one presented in the NFA, and the less discontinuous granulometry of the recycled aggregates, which can change the pores structure of the mixture, and therefore reduces the amount of connected pores in the mortar. The reduction of the air entrained content that was obtained with the addition of higher MFRA contents also has a positive effect on this property.

Table 4 - The mean, the standard deviation, and the coefficient of variation for the water absorption by capillarity of the studied mortars

\begin{tabular}{|c|c|c|c|c|c|c|}
\hline & \multicolumn{2}{|c|}{ REF } & \multicolumn{2}{|c|}{$20 \%$ MFRA } & \multicolumn{2}{|c|}{ 40\% MFRA } \\
\hline & NBR 7215 & MDE & NBR 7215 & MDE & NBR 7215 & MDE \\
\hline $\begin{array}{c}\mathbf{A 1 0} \\
\mathrm{At} \pm \mathrm{SD}(\mathrm{CV}) \\
\mathrm{g} / \mathrm{cm}^{2} \pm \mathrm{g} / \mathrm{cm}^{2}(\%)\end{array}$ & $\begin{array}{c}0.28 \pm 0.01 \\
\quad(3.7)\end{array}$ & $\begin{array}{c}0.25 \pm 0.01 \\
\quad(2.7)\end{array}$ & $\begin{array}{c}0.28 \pm 0.01 \\
\quad(3.5)\end{array}$ & $\begin{array}{c}0.25 \pm 0.01 \\
\quad(5.4)\end{array}$ & $\begin{array}{c}0.26 \pm 0.02 \\
\quad(6.2)\end{array}$ & $\begin{array}{c}0.22 \pm 0.01 \\
\quad(4.3)\end{array}$ \\
\hline $\begin{array}{c}\mathrm{A90} \\
\mathrm{At} \pm \mathrm{SD}(\mathrm{CV}) \\
\mathrm{g} / \mathrm{cm}^{2} \pm \mathrm{g} / \mathrm{cm}^{2}(\%)\end{array}$ & $\begin{array}{c}0.73 \pm 0.01 \\
\quad(1.2)\end{array}$ & $\begin{array}{c}0.70 \pm 0.03 \\
\quad(4.2)\end{array}$ & $\begin{array}{c}0.69 \pm 0.02 \\
\quad(2.6)\end{array}$ & $\begin{array}{c}0.63 \pm 0.02 \\
\quad(3.4)\end{array}$ & $\begin{array}{c}0.66 \pm 0.02 \\
\quad(3.2)\end{array}$ & $\begin{array}{c}0.52 \pm 0.03 \\
\quad(5.1)\end{array}$ \\
\hline $\begin{array}{c}\mathbf{C} \\
\mathrm{C} \pm \mathrm{SD}(\mathrm{CV}) \\
\mathrm{g} / \mathrm{dm}^{2} \cdot \mathrm{min}^{1 / 2} \pm \mathrm{g} / \mathrm{dm}^{2} \\
\min ^{1 / 2}(\%)\end{array}$ & $\begin{array}{c}7.3 \pm 0.09 \\
(1.2)\end{array}$ & $\begin{array}{c}7.2 \pm 0.38 \\
(5.3)\end{array}$ & $\begin{array}{c}6.6 \pm 0.14 \\
(2.2)\end{array}$ & $\begin{array}{c}6.2 \pm 0.07 \\
(1.1)\end{array}$ & $\begin{array}{c}6.6 \pm 0.09 \\
(1.4)\end{array}$ & $\begin{array}{c}5.1 \pm 0.27 \\
(5.2)\end{array}$ \\
\hline
\end{tabular}

Note: $\mathrm{A} 10$ - water absorption by capillarity at 10 min of test;

A90 - water absorption by capillarity at 90 min of test;

C - coefficient of capillarity;

SD - standard deviation; and

$\mathrm{CV}$ - coefficient of variation. 
Figure 8 - Average results of the water absorption by capillarity

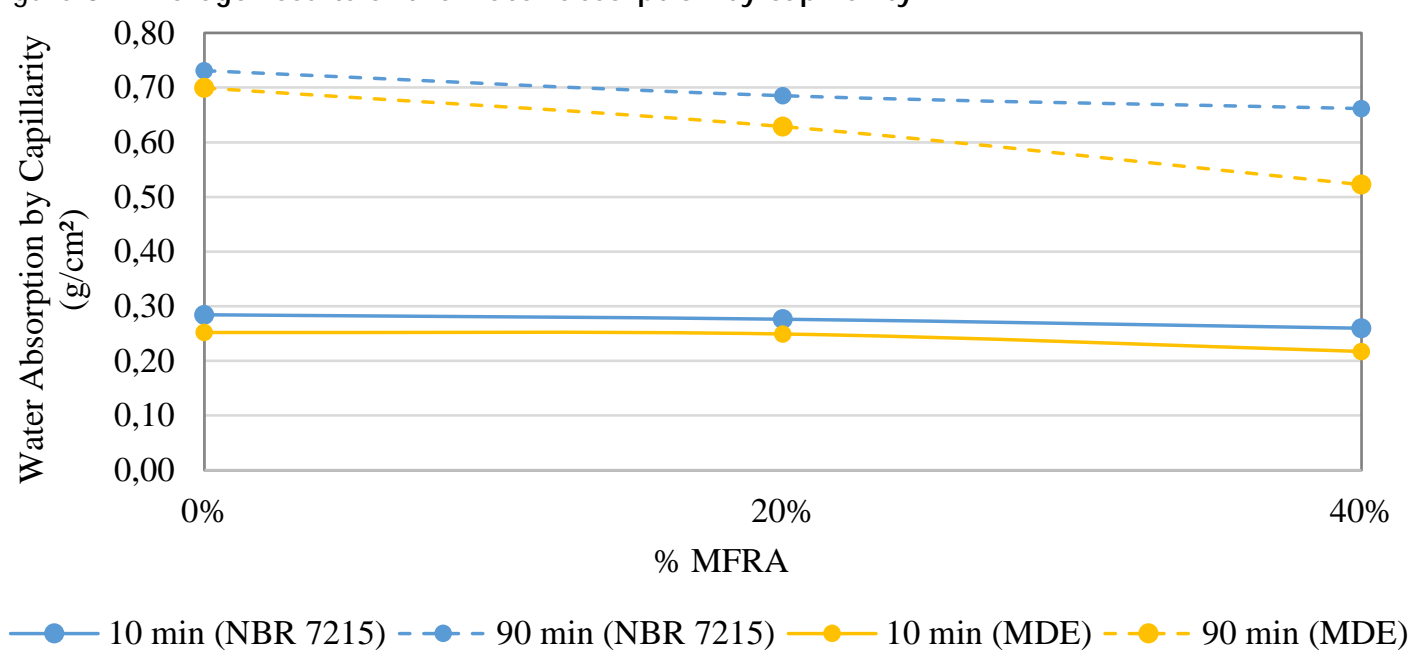

Regarding the reduction of water absorption by capillarity with the adoption of the MDE mixing sequence, this behavior may be related to the lower amount of free water in the mortars, due to the great water absorption by the recycled aggregate that occurs in the first stage of this mixing sequence. Thus, having less free water in the mixture, less water will evaporate, thereby reducing the number, connection and/or size of the pores.

\section{Water absorption rate by immersion, void index and specific gravity}

Based on the results obtained for the real specific gravity shown in Table 5, it is observed that there was a reduction of this property with the increase of the MFRA content, being the greatest reduction (4\%) presented by $40 \%$ MFRA mixture produced with the MDE mixing sequence. Serra, Santana and Cabral (2014), who also worked with MFRA, did not notice any influence of the presence of this aggregate in the specific gravity of the mortars, both in the fresh and in the hardened states. The reduction in the real specific gravity, although small, should be related to the lower specific gravity of the MFRA (about 5\% lower) when compared to the NFA that was used in the production of the mortars.

In order to confirm the influence of the \%MFRA upon the results of absorption rate and void index an analysis of variance (ANOVA) was performed for each group of mortars produced with each mixing sequence. The One-Way ANOVA results are shown in Table 6 . The \% of MFRA was found significant only in the results of the void index for the mortars produced using the MDE mixing sequence, as it is noticed in Figure 9b. Figure 9 makes it evident that there are no differences between the results of absorption rate or void index of mortars produced using the Brazilian standard. But some differences can be seen between the mean values from the mortars made using the MDE mixing sequence. Therefore, an analysis of multiple comparisons of means was additionally performed and it was observed that considering the group of mortars produced with MDE, the mean values of the absorption rate of the mixture 40\%MFRA is significantly different from the absorption rate of the reference mortar. Also, the void index mean value of the $40 \%$ MFRA mixture is significantly different from both REF and 20\%MFRA mixtures.

The slight reduction observed for both water absorption rate and void index, considering the MDE mixing sequence and $40 \%$ of MFRA content, can be a consequence of the decrease of the mortar voids. This reduction of the open porosity must be related to some aspects such as the reduction of the effective mixing water/cement ratio, due to the greater absorption ratio of the recycled aggregate; the lower evaporation of the absorbed water, that is trapped in the grains; and the higher content of fines in the MFRA compared to the NFA, which generates a greater filling of the voids.

\section{Conclusions}

This study showed the great potential of applying the mixture in two stages, or from the Portuguese expression 'mistura em duas etapas', here called MDE mixing sequence, for recycled mortars production using up to $40 \%$ of MFRA. It is worth noting that from the environmental point of view, the viability of using higher substitution levels of the natural aggregates by the recycled ones in the production of mortars is also important. 
Table 5 - The mean, the standard deviation, and the coefficient of variation for the results of water absorption rate by immersion, the void index and the real specific gravity

\begin{tabular}{|c|c|c|c|c|c|c|}
\hline & \multicolumn{2}{|c|}{ REF } & \multicolumn{2}{|c|}{ 20\% MFRA } & \multicolumn{2}{|c|}{ 40\% MFRA } \\
\hline & NBR 7215 & MDE & NBR 7215 & MDE & NBR 7215 & MDE \\
\hline $\begin{array}{c}\text { Water absorption } \\
\text { rate (\%) } \\
\mathrm{A} \pm \mathrm{SD}(\mathrm{CV}) \\
\% \pm \%(\%)\end{array}$ & $\begin{array}{c}13.54 \pm 0.73 \\
(5.4)\end{array}$ & $\begin{array}{c}13.49 \pm 0.42 \\
(3.1)\end{array}$ & $\begin{array}{c}13.17 \pm 0.20 \\
(1.5)\end{array}$ & $\begin{array}{c}13.31 \pm 0.32 \\
(2.4)\end{array}$ & $\begin{array}{c}13.19 \pm 0.41 \\
(3.1)\end{array}$ & $\begin{array}{c}12.82 \pm 0.17 \\
(1.4)\end{array}$ \\
\hline $\begin{array}{c}\text { Void Index (\%) } \\
\mathrm{I}_{\mathrm{V}} \pm \mathrm{SD}(\mathrm{CV}) \\
\% \pm \%(\%)\end{array}$ & $\begin{array}{l}25.4 \pm 1.15 \\
\quad(4.5)\end{array}$ & $\begin{array}{l}25.2 \pm 0.71 \\
\quad(2.8)\end{array}$ & $\begin{array}{c}24.6 \pm 0.30 \\
(1.2)\end{array}$ & $\begin{array}{l}24.9 \pm 0.56 \\
\quad(2.3)\end{array}$ & $\begin{array}{c}24.8 \pm 0.69 \\
(2.8)\end{array}$ & $\begin{array}{c}23.7 \pm 0.33 \\
(1.4)\end{array}$ \\
\hline $\begin{array}{c}\text { Specific gravity } \\
\rho \pm \mathrm{SD}(\mathrm{CV}) \\
\mathrm{g} / \mathrm{cm}^{3} \pm \mathrm{g} / \mathrm{cm}^{3}(\%)\end{array}$ & $\begin{array}{l}2.52 \pm 0.02 \\
\quad(0.8)\end{array}$ & $\begin{array}{l}2.50 \pm 0.02 \\
(0.8)\end{array}$ & $\begin{array}{c}2.48 \pm 0.00 \\
(0.2)\end{array}$ & $\begin{array}{c}2.49 \pm 0.02 \\
(0.8)\end{array}$ & $\begin{array}{c}2.50 \pm 0.02 \\
(0.8)\end{array}$ & $\begin{array}{c}2.43 \pm 0.02 \\
(0.8)\end{array}$ \\
\hline
\end{tabular}

Table 6 - Analyses of variance of the influence of \%MFRA on the water absorption rate and void index for mortars studied using each mixing sequence

\begin{tabular}{|c|c|c|c|c|c|c|c|c|c|c|}
\hline & \multicolumn{5}{|c|}{ Absorption rate - NBR 7215} & \multicolumn{5}{|c|}{ Void Index - NBR 7215} \\
\hline Effects & DF & MS & $\mathbf{F}_{\mathbf{c}}$ & $\mathbf{F}_{0.05}$ & Sg & $\mathbf{D F}$ & MS & $\mathbf{F}_{\mathbf{c}}$ & $\mathbf{F}_{0.05}$ & Sg \\
\hline $\begin{array}{c}\% \\
\text { MFRA }\end{array}$ & 2 & 0.133 & 0.546 & 5.14 & NS & 2 & 0.563 & 0.886 & 5.14 & NS \\
\hline ERROR & 6 & 0.243 & & & & 6 & 0.636 & & & \\
\hline & \multicolumn{5}{|c|}{ Absorption rate - MDE } & \multicolumn{5}{|c|}{ Void Index - MDE } \\
\hline Effects & DF & MS & $\mathbf{F}_{\mathbf{c}}$ & $\mathbf{F}_{0.05}$ & Sg & DF & MS & $\mathbf{F}_{\mathbf{c}}$ & $\mathbf{F}_{0.05}$ & Sg \\
\hline $\begin{array}{c}\% \\
\text { MFRA }\end{array}$ & 2 & 0.362 & 3.51 & 5.14 & NS & 2 & 1.808 & 5.84 & 5.14 & S \\
\hline ERROR & 6 & 0.103 & & & & 6 & 0.31 & & & \\
\hline
\end{tabular}

Note: DF - Degrees of freedom;

MS - Mean square:

$\mathrm{Fc}$ - calculated value of F-test;

$\mathrm{F}_{0.05}-\mathrm{F}$-distribution value for the level of significance of $5 \%$

Sg- Significance;

S - Significant; AND

NS - Not significant.

Figure 9 - Evaluation of the effect of the MRFA content and mixing sequence on studied mortars: (a) Absorption rate; and (b) Void index

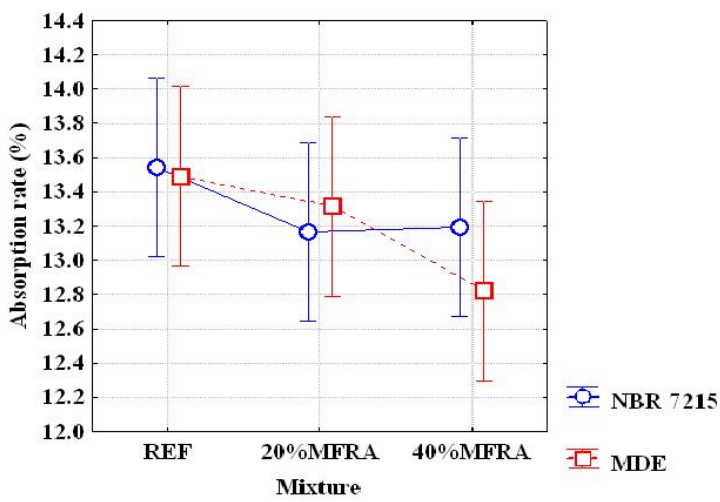

(a)

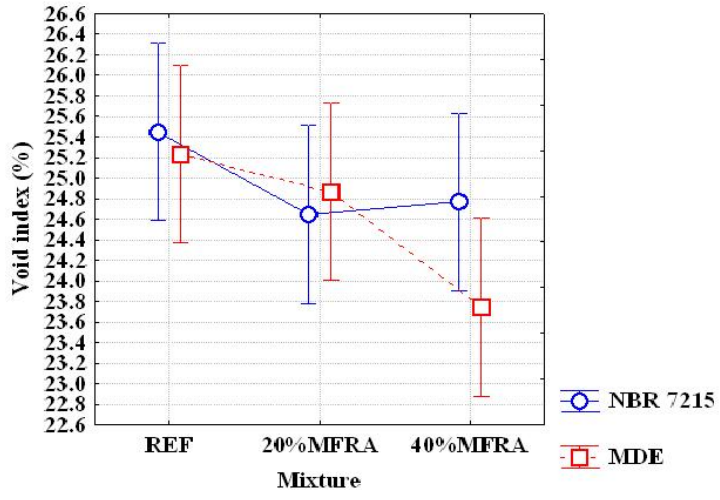

(b)

In the fresh state, an increase of the water retentivity and bulk density and a decrease of the air entrained content of the recycled mortars studied were observed. Such results were quite important to obtain a favorable behavior of the mortars also in

the hardened state. However, the consistence index of the samples reduced while the MFRA content increased. Nevertheless, considering qualitative observations and the ease of placing, compacting and finishing the mortar specimens, the recycled 
mortars maintained themselves workable and slightly dry. In the hardened state, the increase of MFRA content improved the mechanical performance of traction and compression, at 7 and 28 days, mainly because of the reduction of the effective water/cement ratio, generated by the water absorption of the grain pores of the MFRA.

In relation to the influence of the mixing sequence, adopting the MDE, this method revealed itself more suitable to the recycled mortars' production, when compared to the mixing sequence of the Brazilian standard NBR 7215 (ABNT, 1996). The MDE mixing sequence presents a higher total mixing time and also allows a higher absorption of the mixing water by the recycled aggregates compared to the mortars produced with the Brazilian standard NBR 7215 (ABNT, 1996) mixing sequence. Such aspects should have favored the greater removal of water from the system. Thus, these factors can be considered as one of the causes for the reduction of the effective amount of water in the recycled mixtures, reducing the consistency index and improving the properties in the hardened state. In order to overcome the reduction of the consistence index it is necessary to perform new studies in recycled mortars using the MDE mixing sequence making adjustments on the workability by using or the increase of the water/cement ratio or the incorporation of chemical admixtures. Also, it is necessary to perform additional tests to determine important mortar properties, such as shrinkage and bond strength, mainly to determine the applicability of the recycled mortars achieved.

\section{References}

ANTUNES, R. P. N.; JOHN, V.; PILEGGI, R. G. Influência da Sequência de Mistura nas Propriedades Reológicas de Argamassas Avaliada por Squeeze-Flow. In: SIMPÓSIO BRASILEIRO DE TECNOLOGIA DAS ARGAMASSAS, 6.; International Symposium on Mortars Technology, 1., Brasília, 2006. Anais... São Paulo: ANTAC, 2006.

ASSOCIAÇÃO BRASILEIRA DE NORMAS

TÉCNICAS. NBR 5733: cimento Portland de alta resistência inicial. Rio de Janeiro, 1991.

ASSOCIAÇÃO BRASILEIRA DE NORMAS TÉCNICAS. NBR 7215: cimento Portland: determinação da resistência à compressão. Rio de Janeiro, 1996.

ASSOCIAÇÃO BRASILEIRA DE NORMAS

TÉCNICAS. NBR NM 248: agregado: determinação da composição granulométrica. Rio de Janeiro, 2003.
ASSOCIAÇÃO BRASILEIRA DE NORMAS TÉCNICAS. NBR 9778: argamassa e concreto endurecidos: determinação da absorção de água, índice de vazios e massa específica. Rio de Janeiro, 2005a.

\section{ASSOCIAÇÃO BRASILEIRA DE NORMAS} TÉCNICAS. NBR 13276: argamassa para assentamento e revestimento de paredes e tetos: preparo da mistura e determinação do índice de consistência. Rio de Janeiro, 2005b.

\section{ASSOCIAÇÃO BRASILEIRA DE NORMAS}

TÉCNICAS. NBR 13277: argamassa para assentamento e revestimento de paredes e tetos: determinação da retenção de água. Rio de Janeiro, 2005c.

\section{ASSOCIAÇÃO BRASILEIRA DE NORMAS TÉCNICAS. NBR 13278: argamassa para} assentamento e revestimento de paredes e tetos: determinação da densidade de massa e do teor de ar incorporado. Rio de Janeiro, 2005d.

\section{ASSOCIAÇÃO BRASILEIRA DE NORMAS \\ TÉCNICAS. NBR 13279: argamassa para assentamento e revestimento de paredes e tetos: determinação da resistência à tração na flexão e à compressão. Rio de Janeiro, 2005e.}

\section{ASSOCIAÇÃO BRASILEIRA DE NORMAS TÉCNICAS. NBR 15259: argamassa para} assentamento e revestimento de paredes e tetos: determinação da absorção de água por capilaridade e do coeficiente de capilaridade. Rio de Janeiro, $2005 f$.

\section{ASSOCIAÇÃO BRASILEIRA DE NORMAS} TÉCNICAS. NBR NM 30: agregado miúdo: determinação da absorção de água. Rio de Janeiro, 2001.

\section{ASSOCIAÇÃO BRASILEIRA DE NORMAS TÉCNICAS. NBR NM 46: agregados:} determinação do material fino que passa através da peneira $75 \mu \mathrm{m}$, por lavagem. Rio de Janeiro, 2003.

ASSOCIAÇÃO BRASILEIRA DE NORMAS TÉCNICAS. NBR NM 52: agregado miúdo: determinação da massa específica e massa específica aparente. Rio de Janeiro, 2009.

\section{ASSOCIAÇÃO BRASILEIRA PARA RECICLAGEM DE RESÍDUOS DA CONSTRUÇÃO CIVIL E DEMOLIÇÃO.} Relatório Pesquisa Setorial 2014/2015. São Paulo, 2015.

BRAGA, M.; BRITO, J.; VEIGA, R. Incorporation of Fine Concrete Aggregates in Mortars. Construction and Building Materials, v. 36, p. 960-968, 2012. 
CORINALDESI, V.; MORICONE, G. Behavior of Cementitious Mortars Containing Different Kinds of Recycled Aggregate. Construction and Building Materials, v. 23, p. 289-294, 2009.

FIGUEIRÊDO FILHO, J. G. L. Avaliação da Trabalhabilidade de Concretos Contendo Agregado Reciclado de Argamassa. Feira de Santana, 2011. Dissertação (Mestrado em Engenharia Civil) - Programa de Pós-Graduação em Engenharia Civil e Ambiental, Universidade Estadual de Feira de Santana, Feira de Santana, 2011.

GOMES, P. C. C. et al. Obtenção de Argamassas Com Agregados Reciclados Produzidos na Obra Para Uso em Revestimento. In: ENCONTRO NACIONAL DE TECNOLOGIA DO AMBIENTE CONSTRUÍDO, 13., Canela, 2010. Anais... São Paulo: ANTAC, 2010.

HIGASHIYAMA, H. et al. Chloride Ion Penetration Into Mortar Containing Ceramic Waste Aggregate. Construction and Building Materials, v. 33, p. 48-54, 2012.

LE, T. et al. Hardened Behavior of Mortar Based on Recycled Aggregate: influence of saturation state at macro- and microscopic scales.

Construction and Building Materials, v. 141, p. 479-490, 2017.

LOVATO, P. S.; MENEGATTI, R. Influência da Pré-Umidificação do Agregado Reciclado de Resíduos da Construção Civil nas Propriedades de Argamassas de Revestimento. In: SIMPÓSIO BRASILEIRO DE TECNOLOGIA DAS ARGAMASSAS, 11., Porto Alegre, 2015. Anais... São Paulo: ANTAC, 2015.

MALTA, J. O. et al. Influência da Pré-Saturação do Agregado Miúdo Reciclado na Viscosidade e Resistência à Compressão de Argamassas.

Ambiente Construído, Porto Alegre, v. 14, n. 1, p. 85-98, jan./mar. 2014.

MALTA, J. O.; SILVA, V. S.; GONÇALVES, J. P. Argamassa Contendo Agregado Miúdo Reciclado de Resíduo de Construção e Demolição. Revista Eletrônica de Gestão e Tecnologias, v. 1, p. 176-188, 2013.

MARTÍNEZ, I. et al. A Comparative Analysis of the Properties of Recycled and Natural Aggregate in Masonry Mortars. Construction and Building Materials, v. 49, p. 384-392, 2013.

MARTINÉZ, P. S. et al. Comparative Study of Three Types of Fine Recycled Aggregates From Construction and Demolition Waste (CDW), and Their Use in Mansory Mortar Fabrication. Journal of Cleaner Production, v. 118, p. 162-169, 2016.
MIRANDA, L. F. R. Estudo de Fatores Que Influenciam na Fissuração de Revestimento de Argamassa Com Entulho Reciclado. São Paulo, 172 f. Dissertação (Mestrado em Engenharia Civil) - Escola Politécnica, Universidade de São Paulo, São Paulo, 2000.

MIRANDA, L. F. R.; SELMO, S. M. S. CDW Recycled Aggregate Renderings: part I: analysis of the effect of materials finer than $75 \mu \mathrm{m}$ on mortar properties. Construction and Building Materials, v. 20, p. 615-624, 2006.

NENO, C.; BRITO, J.; VEIGA, R. Using Fine Recycled Concrete Aggregate For Mortar Production. Materials Research, v. 17, n. 1, p. 168-177, 2014.

OLIVEIRA, M. E. D.; CABRAL, A. E. B. Argamassas de Revestimento Produzidas Com Agregado Reciclado de Fortaleza/CE, Brasil. Engenharia Civil UM, Braga, v. 41, n. 41, p. 2134, 2011.

OLIVEIRA, M. E. D. Agregado Reciclado de Construção e Demolição: influência em propriedades de argamassas para revestimento. Feira de Santana, 2012. Dissertação (Mestrado em Engenharia Civil) - Programa de Pós-Graduação em Engenharia Civil e Ambiental, Universidade Estadual de Feira de Santana, Feira de Santana, 2012.

RESTUCCIA, L.; SPOTO, C.; FERRO, G. A.; Recycled Mortars With C\&D Waste. Procedia Structural Integrity, v. 2, p. 2896-2904, 2016.

ROMANO, R. C. O. et al. Efeito do Tempo de Mistura nas Propriedades de Argamassas Com Ar Incorporado. In: SIMPÓSIO BRASILEIRO DE TECNOLOGIA DAS ARGAMASSAS, 7., Recife, 2007. Anais... São Paulo: ANTAC, 2007.

SERRA, J. H. F.; SANTANA, L. B.; CABRAL, A. E. B. Avaliação da Reutilização de Agregados Reciclados de Argamassa na Produção de Emboço. In: ENCONTRO NACIONAL DE

TECNOLOGIA DO AMBIENTE CONSTRUÍDO, 15., Maceió, 2014. Anais... São Paulo: ANTAC, 2014.

SILVA, E. C. R. et al. Desempenho de Revestimentos Com Areias Recicladas Produzidas em Canteiro de Obras. In: SIMPÓSIO BRASILEIRO DE TECNOLOGIA DAS ARGAMASSAS, 9., Belo Horizonte, 2011. Anais... São Paulo: ANTAC, 2011.

SILVA, J.; BRITO, J.; VEIGA, R. Incorporation of Fine Ceramics in Mortars. Construction and Building Materials, v. 23, p. 556-564, 2009. 
SOUZA, C. A. Utilização de Resíduos de Concreto Como Agregado Miúdo Para Argamassa de Concretos Estruturais Convencionais. Belo Horizonte, 2006. 240 f. Dissertação (Mestrado) - Escola de Engenharia da UFMG, Universidade Federal de Minas Gerais, Belo Horizonte, 2006.
TAM, V. W. Y.; GAO, X. F.; TAM, C. M. MicroStructural Analysis of Recycled Aggregate Concrete Produced From Two-Stage Mixing Approach. Cement Concrete Research, v. 35, p. 1195-1203, 2005.

\title{
Gilberto Alves da Silva Neto
}

Departamento de Tecnologia, Laboratórios de Tecnologia | Universidade Estadual de Feira de Santana | Av. Transnordestina, s/n, Campus Universitário, Novo Horizonte | Feira de Santana - BA - Brasil | CEP 44036-900 | Tel.: (75) 3625-8549| E-mail:

gilbertoalves.eng@gmail.com

\section{Mônica Batista Leite}

Departamento de Tecnologia, Programa de Pós-graduação em Engenharia Civil e Ambiental| Universidade Estadual de Feira de Santana Av. Transnordestina, s/n, Campus Universitário, Novo Horizonte | Feira de Santana - BA - Brasil | CEP 44036-900 | Tel.: (75) 3161-8117 | E-mail: mleite.uefs@gmail.com

\author{
Revista Ambiente Construído \\ Associação Nacional de Tecnologia do Ambiente Construído \\ Av. Osvaldo Aranha, 99 - 3o andar, Centro \\ Porto Alegre - RS - Brasil \\ CEP $90035-190$ \\ Telefone: +55 (51) 3308-4084 \\ Fax: +55 (51) 3308-4054 \\ www. seer. ufrgs. br/ ambienteconstruido \\ E-mail: ambienteconstruido@ufrgs.br
}

(c) () (i) This is an open-access article distributed under the terms of the Creative Commons Attribution License. 